RESEARCH ARTICLE

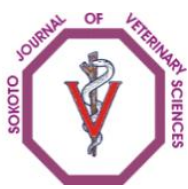

Sokoto Journal of Veterinary Sciences

(P-ISSN 1595-093X/ E-ISSN 2315-6201)

Oluwayelu et al/Sokoto Journal of Veterinary Sciences (2015) 13(3): 14-18

http://dx.doi.org/10.4314/sokjvs.v13i3.3

\title{
Serological screening for Schmallenberg virus in exotic and indigenous cattle in Nigeria
}

\author{
DO Oluwayelu ${ }^{1 *}$, CA Meseko ${ }^{2} \&$ Al Adebiyi $^{1}$
}

\section{Department of Veterinary Microbiology \& Parasitology, University of Ibadan, Ibadan, Nigeria. \\ 2. Virology Department, National Veterinary Research Institute, Vom, Nigeria}

*Correspondence: Tel.: +2348067618544, E-mail: ogloryus@yahoo.com

\begin{abstract}
Schmallenberg virus (SBV), a recently emerged Orthobunyavirus, is associated with abortions, stillbirths and congenital malformations in ruminants. Considering that Culicoides species which transmit this disease have previously been identified in Nigeria as vectors of bluetongue, another livestock disease that causes abortions, it is speculated that SBV also circulates in the Nigerian ruminant population. We therefore conducted a pilot study to investigate the occurrence of anti-SBV antibodies in a limited population of cross-breed, exotic and indigenous cattle in Nigeria. Serum samples obtained from 60 Friesian-White Fulani (FWF), 7 Jersey and 53 indigenous cattle were screened for SBV antibodies using a commercial indirect ELISA kit that detects antibodies against recombinant SBV nucleoprotein in ruminant sera. An overall seropositivity of $29.2 \%$ $(35 / 120)$ was obtained with antibodies being detectable in $23.3 \%$ FWF (14/60), $42.9 \%$ Jerseys (3/7) and $34.0 \%$ $(18 / 53)$ indigenous cattle. All indigenous breeds of cattle tested had seropositive animals: White Fulani (13/38, $34.2 \%)$, Sokoto Gudali $(2 / 8,25.0 \%)$, Red Bororo (1/5, 20.0\%) and Bunaji $(2 / 2,100.0 \%)$. The detection of antibody-positive animals among unvaccinated cattle provides evidence of possible SBV infection in Nigeria. However, there is also the probability of cross-reactivity with other Simbu serogroup viruses, especially considering that some of these viruses have previously been reported in Nigeria. Further studies to confirm these preliminary findings using serum neutralisation assay, viral isolation or detection of SBV RNA from ruminants or Culicoides are necessary.
\end{abstract}

Keywords: Abortions, Antibodies, Cattle, Congenital malformations, Nigeria, Schmallenberg virus

Received: 25-06- 2015

Accepted: 04-09-2015

\section{Introduction}

Schmallenberg virus (SBV), a novel member of the family Bunyaviridae, genus Orthobunyavirus was first reported in cattle from Germany and The Netherlands in 2011 (Hoffmann et al., 2012). It is an enveloped, negative-sense, segmented, singlestranded RNA virus that is closely related to Shamonda virus (SHAV), which belongs to the Simbu serogroup of viruses that includes Sango, Sabo and Shuni viruses (Causey et al., 1972; Goller et al., 2012). The virus is associated with abortions, stillbirths and congenital malformations in cattle, sheep and, much less frequently, goats (Beer et al., 2013). Since the first cases from Germany and The Netherlands, SBV has caused a large epidemic in ruminants with several reports of clinical manifestation and serologic evidence of the disease mostly from European countries (Doceul et al., 2013).
Apart from a retrospective report of suspected SBV infection of lambs in South Africa and the recent detection in Mozambique of SBV antibodies in ruminants (Leask et al., 2013; Blomstrom et al., 2014), there is limited information on the disease in Africa. In Nigeria, although there are no reports of SBV infection in ruminants hitherto, congenital malformations associated with SBV such as arthrogryposis, kyphosis, scoliosis and brachygnathia inferior have been reported among Nigerian ruminants (Ibrahim et al., 1987; Ate \& Allam, 2002; Ibrahim et al., 2006). Moreover, several Culicoides species identified as vectors of SBV have previously been identified in Nigeria (Dipeolu \& Ogunrinade, 1977). Since these Culicoides vectors also transmit bluetongue virus (BTV) which causes abortions in ruminants and has been reported in Nigeria (Herniman et al., 1983), it is hypothesized that SBV infection is prevalent in 
Nigeria but its diagnosis might have been missed because it produces clinical signs and pathology similar to those caused by other known disease agents such as BTV. Thus, in this pilot study, we investigated the presence of anti-SBV antibodies in a limited number of cross-breed, exotic and indigenous cattle in Nigeria.

\section{Materials and methods}

Serum collection was carried out from 120 cattle comprising 60 adult Friesian-White Fulani (FWF), seven Jersey ( 5 adults and 2 calves) and 53 adult indigenous cattle. The FWF, which are crossbreeds between Friesians imported from The Netherlands over three decades ago and White Fulani cattle, were managed intensively on a private dairy farm in Jos, Plateau state while the adult Jersey cattle, whose country of origin could not be ascertained, were reared privately with their calves in Ibadan, Oyo state. The indigenous cattle belonged to four breeds: White Fulani $(n=38)$, Sokoto Gudali $(n=8)$, Red Bororo $(n=5)$, and Bunaji $(n=2)$ and were located in Abeokuta (Ogun state), Ibadan (Oyo state), Ejigbo (Osun state) and Badagry (Lagos state) (Figure 1). Most of them were managed intensively on privately-owned farms while a few were transported from northern Nigeria for slaughter in major cattle markets in the southwest region. Sera from the FWF were archived samples collected in January 2011 while those from the indigenous and Jersey cattle were collected between March and July 2012, and in January 2013, respectively. The sera were screened for SBV antibodies using the commercial ID Screen Schmallenberg virus indirect ELISA kit (IDvet, Montpellier, France) that detects antibodies against recombinant SBV nucleoprotein in ruminant sera and was reported by the manufacturer to have excellent $(98.9 \%)$ correlation with the virus neutralization test. The ELISA was performed according to the instructions of the manufacturer and assay characteristics as reported in the manufacturer's validation data were a relative sensitivity of $96.47 \%(95 \% \mathrm{Cl}$ : $93.43-$ 98.13\%) and specificity of $99.75 \%$ (95\% Cl: $99.26-$ 99.92\% (IDvet, 2012). Results were expressed as $S / P$ percentage $(S / P \%)$ using the optical densities (OD) from the ELISA reader $\left(S / P \%=O D_{\text {sample }} /\right.$ $O D_{\text {positive control }} \times 100$ ). Samples that presented $S / P \%$ lower or equal to $60 \%$, between $60 \%$ and $70 \%$, and $>70 \%$ were considered negative, doubtful and positive respectively. Data obtained were analysed with Graph Pad prism version 5.0 (Graph Pad software, San Diego, USA) and p-values < 0.05 were considered significant. Using two-tailed Fisher's exact test, prevalence rates were compared based on region of sample collection and breed of cattle.

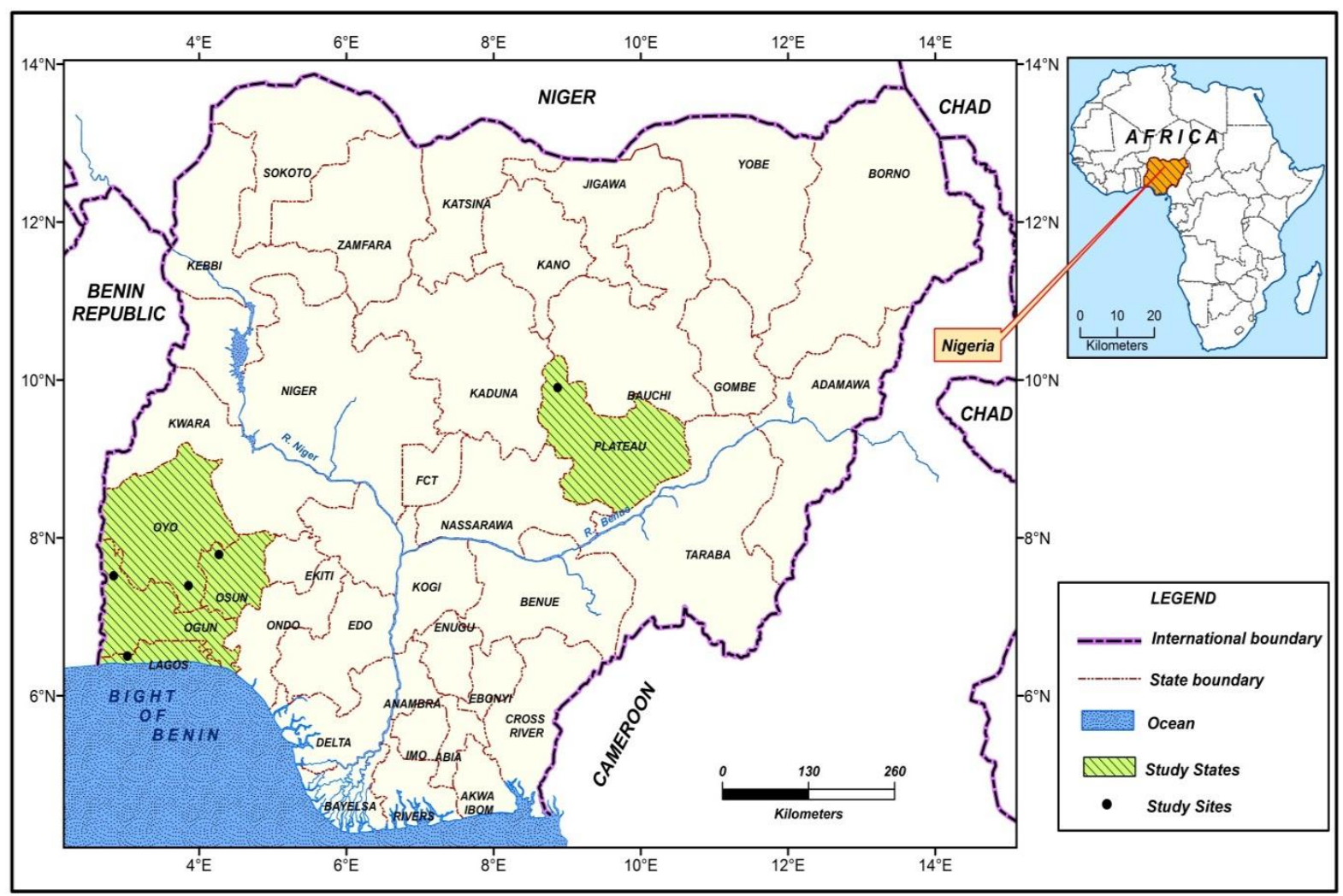

Figure 1: Map of Nigeria showing sample collection sites 
Table 1: Seroprevalence of Schmallenberg virus in tested cattle samples

\begin{tabular}{lllll}
\hline Breed of cattle & No. sampled & Positive (\%) & Doubtful (\%) & Negative (\%) \\
\hline Friesian-White Fulani & 60 & $14(23.3)$ & $4(6.7)$ & $42(70.0)$ \\
Jersey & 7 & $3(42.9)$ & $1(14.3)$ & $3(42.9)$ \\
Indigenous & 53 & $18(34.0)$ & $7(13.2)$ & $28(52.8)$ \\
Total & 120 & $35(29.2)$ & $12(10.0)$ & $73(60.8)$ \\
\hline
\end{tabular}

\section{Results}

Thirty-five (29.2\%) of the 120 sera tested reacted against recombinant SBV nucleoprotein antigen with $12(10.0 \%)$ and $73(60.8 \%)$ being doubtful and negative, respectively (Table 1). Specifically, antibody-positive animals were 14 FWF (23.3\%), 3 Jersey $(42.9 \%)$ and 18 indigenous cattle (34.0\%). For the indigenous cattle, seropositivity was $34.2 \%$ (13/38), 25.0\% (2/8), 20.0\% (1/5) and 100.0\% (2/2) among White Fulani, Sokoto Gudali, Red Bororo and Bunaji breeds, respectively. Although a higher SBV seroprevalence (35.0\%) was obtained for cattle from the Southwest region compared to those from the North-Central (23.3\%), the difference was not statistically significant.

\section{Discussion}

The findings of this study provide a first indication of the possible circulation of SBV infection in cattle in Nigeria. As vaccination against SBV is not currently practised in the country, the detection of seropositive animals among the tested cattle suggests natural exposure of these animals to the virus. Considering that the FWF cattle sera were collected in January 2011, this finding of antibodypositive animals presupposes that the virus may have existed in Nigeria, at least, as far back as 2011 when the first outbreak of the disease was recorded in Europe. Our detection of positive reactors among cattle in this study is consistent with the report of Azkur et al. (2013) who also found SBV-positive animals in Turkey using the same ELISA kit and concluded, based on personal communication with the manufacturer, that antibodies detected in the screened animals were actually due to SBV and not a related virus like Akabane virus (AKAV).

However, the possibility that the antibodies could be due to cross-reactivity with other Simbu serogroup viruses cannot be completely excluded. This possibility is particularly relevant to the present study because SHAV and Sathuperi virus (SATV) were originally isolated in Nigeria (Causey et al., 1972), and it is likely that other currently unidentified Simbu viruses might be present in the country. Moreover, SBV is reported to be a reassortant having the $S$ and $L$ RNA segments from SHAV and the $M$ segment from SATV (Yanase et al., 2012). The prospect of cross-reactivity as it relates to the Nigerian (or African) origin of some of these Simbu viruses is underscored by the report of Kupferschmidt (2012) in which it was proposed that SBV could have gained entry into Europe through insects imported on aircraft, or with an infected animal or cut flowers from subSaharan Africa. Furthermore, in a study to validate the commercial ELISA used for the current investigation, Bréard et al. (2013) reported that despite limited cross-reactions observed with sera from ruminants experimentally infected with AKAV, cross-reactivity with other members of the Simbu serogroup such as SHAV and SATV cannot be ruled out using this ELISA.

Although $23.3 \%$ and $42.9 \%$ SBV seropositivity were detected in FWF and Jersey cattle sampled respectively, our study could not ascertain whether the exotic cattle (Friesian component of FWF and Jersey) acquired the infection locally or were already incubating the disease at the time of their importation into Nigeria. Also, since there is illegal transborder movement of ruminants from neighbouring West African countries, it is possible that some of the seropositive indigenous cattle could have imported the disease into the country. This highlights the need for screening of all imported animals for both endemic and emerging infectious disease agents. Moreover, the detection of seropositive animals among exotic and indigenous cattle located in different geographical regions of Nigeria suggests that the disease is not breed-restricted and that the virus is present over a large area of the country, being likely sustained by the activity of Culicoides vectors.

Except for the report of suspected SBV infection in South Africa (Leask et al., 2013) and recent serologic evidence of the disease in Mozambique (Blomstrom et al., 2014), the infection has so far been reported only from Europe and Asia (Doceul et al., 2013; Azkur et al., 2013). Therefore, our detection of seropositive cattle in Nigeria indicates that SBV infection may actually be more widespread in distribution than previously believed. Coupled with previous reports of congenitally malformed sheep in Nigeria (Ibrahim et al., 1987; Ate \& Allam, 2002), the results of this study suggest that Nigerian sheep may also be infected with SBV or other related Simbu serogroup viruses since the latter are usually reared with cattle. Furthermore, it is possible that SBV infection may have been present for some time in Nigeria but cases were wrongly attributed to BTV as the latter also causes abortions, stillbirths and congenital malformations. 
Although the findings of this study provide an indication that SBV is present in Nigeria, further investigations based on serum neutralisation test, viral isolation and/or detection and sequencing of SBV RNA from ruminants that have stayed only in Nigeria or from Culicoides would be critical to conclude that SBV has emerged in the country. Additionally, even though SBV is not yet a notifiable disease, we advocate that veterinarians

\section{References}

Ate IU \& Allam L (2002). Multiple congenital skeletal malformations in a lamb associated with dystocia in a Yankasa ewe. Nigerian Veterinary Journal, 23 (1): 61-63.

Azkur AK, Albayrak H, Risvanli A, Pestil Z, Ozan E, Yilmaz O, Tonbak S, Cavunt A, Kadi H, Macun HC, Acar D, Ozenc E, Alparslan S \& Bulut H (2013). Antibodies to Schmallenberg virus in domestic livestock in Turkey. Tropical Animal Health \& Production, 45(8): 1825-1828.

Beer M, Conraths FJ \& van der Poel WH (2013). Schmallenberg virus - a novel orthobunyavirus emerging in Europe. Epidemiology and Infection, 141(1): 1-8.

Blomstrom AL, Stenberg H, Scharin I, Figueiredo J, Nhambirre O, Abilio AP, Fafetine J \& Berg $M$ (2014). Serological screening suggests presence of Schmallenberg virus in cattle, sheep and goat in the Zambezia Province, Mozambique. Transboundary and Emerging Diseases, 61(4): 289-292.

Bréard E, Lara E, Comtet L, Viarouge C, Doceul V, Desprat A, Vitour D, Pozzi N, Cay $A B$, Regge ND, Pourquier $P$, Schirrmeier $H$, Hoffmann B, Beer M, Sailleau C \& Zientara $S$ (2013). Validation of a commercially available indirect ELISA using a nucleocapsid recombinant protein for detection of Schmallenberg virus antibodies. PLoS One, 8(1): e53446. doi:10.1371/journal.pone.0053446.

Causey OR, Kemp GE, Causey CE \& Lee VH (1972). Isolations of Simbu-group viruses in Ibadan, Nigeria 1964-69, including the new types Sango, Shamonda, Sabo and Shuni. Annals of Tropical Medicine and Parasitology, 66(3): 357-362.

Dipeolu OO \& Ogunrinade AF (1977). Studies on Culicoides species of Nigeria. VII. The biology of some Nigerian Culicoides species. Zeitschrift fur Parasiten, 51(3): 289-298.

Doceul V, Lara E, Sailleau C, Belbis G, Richardson J, Bréard $E$, Viarouge $C$, Dominguez $M$, and farmers be encouraged to report cases of abortions, stillbirths and congenital malformations in ruminants to appropriate authorities.

\section{Acknowledgement}

We gratefully acknowledge the farmers and slaughterhouse workers for granting access to their animals and assisting with sample collection.

Hendrikx P, Calavas D, Desprat A, Languille J, Comtet $L$, Pourquier $P$, Eléouët J-F, Delmas B, Marianneau P, Vitour D \& Zientara S (2013). Epidemiology, molecular virology and diagnostics of Schmallenberg virus, an emerging orthobunyavirus in Europe. Veterinary Research, 44: 31.

Goller KV, Höper D, Schirrmeier H, Mettenleiter TC \& Beer M (2012). Schmallenberg virus as possible ancestor of Shamonda virus. Emerging Infectious Diseases, 18(10): 1644-1646.

Herniman KAJ, Boorman JP \& Taylor WP (1983). Bluetongue virus in a Nigerian dairy cattle herd. 1. Serological studies and correlation of virus activity to vector population. Journal of Hygiene (Cambridge), 90(2): 177-193.

Hoffmann B, Scheuch M, Höper D, Jungblut R, Holsteg $M$, Schirrmeier $H$, Eschbaumer $M$, Goller KV, Wernike K, Fischer $M$, Breithaupt A, Mettenleiter TC \& Beer M (2012). Novel Orthobunyavirus in cattle, Europe, 2011. Emerging Infectious Diseases, 18(3): 469-472.

Ibrahim ND, Adamu S, Useh SM, Salami SO, Fatihu MY, Sambo SJ, Mohammed B, Ojo SA \&

Esievo KAN (2006). Multiple congenital defects in a Bunaji bull. Nigerian Veterinary Journal, 27 (3): 80-86.

Ibrahim NDG, Gyang EO \& Njoku CO (1987). Multiple congenital malformations associated with incomplete twinning in Yankassa sheep. Zariya Veterinarian, 2 (2): 81-82.

IDvet (2012). Technical and validation data, ID Screen Schmallenberg virus Indirect.

Kupferschmidt K (2012). Scientists rush to find clues on new animal virus. Science, 335(6072): 1028-1029.

Leask R, Botha AM \& Bath GF (2013). Schmallenberg virus - Is it present in South Africa? Journal of South African Veterinary Association, 84 (1), Art. \#535, 4 http://dx.doi.org/10.4102/jsava.v84i1.535 
Yanase $T$, Kato T, Aizawa M, Shuto $Y$, Shirafuji $H$, Yamakawa M \& Tsuda T (2012). Genetic reassortment between Sathuperi and Shamonda viruses of the genus
Orthobunyavirus in nature: implications for their genetic relationship to Schmallenberg virus. Archives of Virology, 157(8): 1611-1616. 